\title{
PEMANFAATAN MEDIA FLIP CHART UNTUK PENGUATAN LITERASI SAINS SISWA SMP PADA MATERI PENCEMARAN LINGKUNGAN
}

\author{
Yen Sastri ${ }^{1)}$, Evi Suryawati ${ }^{2)}$, Mariani Natalina $\mathbf{L}^{3)}$ \\ E-mail: yen.sastri5250@student.unri.ac.id \\ ${ }^{122) 3)}$ Program Studi Pendidikan Biologi, FKIP Universitas Riau
}

\begin{abstract}
This research aims to determine the effect of using flip chart on students' scientific literacy on environmental pollution material. This development research used ADDIE model which is analyze, design, development, implementation and evaluation. This research was carried out until the development phase. The flip chart that have been produced validated by using validation sheets by 4 validators who expert on media and material, then tested on 20 grade VIII junior high school student. The data of Students' responses about flip chart were collected by using a questionnaire and students' science literacy were collected by using multiple choice test. The results of the research indicated that Flip Chart was valid with score 88,3\% (very valid) in material and $87,5 \%$ (very valid) in media. The result of this result also indicated that there was an increase in the mean score of pre-test and post-test from 62 (low) to 81 (high). It illustrated that there was a strengthening of science literacy on the competence to explain phenomena scientifically from $61.25 \%$ (low) to $87.5 \%$ (very high), the competence to design and evaluate scientific enquiry from $53.75 \%$ (low) to $71.25 \%$ (enough), and the competence to interpret data and evidence scientifically from $80 \%$ (high) to $87.5 \%$ (very high). This result was supported by student questionnaires when using flip chart, which is 88.75 , it shows that flip charts can be used as a means of strengthening student scientific literacy.
\end{abstract}

Keywords: Flip chart, Junior high school,Scientific literacy.

\section{PENDAHULUAN}

Arus perkembangan dan globalisasi yang sedang marak terjadi di Abad 21 berdampak pada munculnya berbagai tantangan dan persaingan dalam kehidupan, sehingga setiap individu perlu berupaya menjadi pribadi yang sigap terhadap berbagai bentuk perkembangan dan permasalahan global. Terdapat beberapa masalah global yang menjadi tanggung jawab individu untuk dapat memecahkannya. Permasalahan tersebut antara lain pencemaran, pemanasan global, pembakaran hutan, dan lainnya.

Provinsi Riau adalah salah satu provinsi yang mengalami masalah lingkungan akibat kurangnya kepekaan terhadap alam setiap tahun, yaitu kebakaran hutan, penambangan emas tanpa izin, dan limbah domestik. Kebakaran hutan Riau pada tahun 2019 menurut BMKG, (2019) terjadi di empat kabupaten, yaitu di Kabupaten Siak, Rokan Hilir, Pelalawan dan Meranti. Masalah sampah domestik adalah masalah yang telah terjadi di Kota Pekanbaru sejak 2016. Penambangan Emas Tanpa Izin (PETI) merupakan permasalahan mendasar bagi masyarakat karena berdampak langsung terhadap kualitas air dan tanah.

Menurut Khaidir et al. (2019) level urbanisasi yang tinggi di kota Pekanbaru dan mobilitas perkotaan menjadi penyebab sering ditemukan tumpukan sampah di berbagai tempat yang tidak seharusnya. Hal inilah yang menjadi pemicu terjadinya dampak negatif yang akan sangat mengganggu dan dapat mengakibatkan keluhan dan gangguan kesehatan bagi masyarakat kota besar seperti 
Kota Pekanbaru. Menurut Pazli, (2020) penambangan emas tanpa izin berdampak luas pada ketersediaan sumber daya alam dan lingkungan secara sistemik. Penggunaan merkuri dalam proses penambangan emas untuk memisahkan emas dengan senyawa lain akan mempengaruhi rantai flora dan fauna. penambangan emas tanpa izin telah mengubah tatanan alam sumber daya air seperti sungai dan danau atau rawa di area pertambangan. Jika permasalahanpermasalahan ini terus dibiarkan begitu saja akan terjadi kerusakan lingkungan parah di Provinsi Riau dalam beberapa tahun kedepan.

Pendidikan berperan penting sebagai salah satu sarana dalam mengatasi pemecahan permasalahan global. Dalam Permendikbud No. 35 tahun 2018 disebutkan bahwa pengembangan kurikulum 2013 dilakukan untuk menjawab tantangan zaman abad 21 yang terkait dengan permasalahan global. Pemecahan masalah global dapat dilakukan melalui penguasaan pemahaman sains (Amining Rahmasiwi et al. 2018). Kemampuan untuk memecahkan masalah berdasarkan penguasaan pemahaman sains disebut dengan literasi sains atau dengan kata lain literasi sains merupakan kemampuan menerapkan ilmu sains dalam memahami dan memecahkan masalah-masalah sains dan sosial dalam kehidupan (Ika Budi Y. et al. 2016). Literasi sains membantu siswa untuk membentuk pola pikir, perilaku, dan membangun karakter untuk peduli dan bertanggung jawab terhadap dirinya, masyarakat, dan alam semesta, serta permasalahan yang dihadapi masyarakat modern yang sangat bergantung pada teknologi.

Hasil Studi PISA menunjukkan bahwa tingkat literasi sains siswa Indonesia masih rendah dan di bawah rata-rata OECD. Pengukuran literasi sains yang terakhir dilakukan pada tahun 2018 menunjukkan bahwa rata-rata nilai literasi sains siswa Indonesia adalah 396 yaitu berada pada level 1a yang artinya turun dibandingkan dengan tahun 2015 yang mendapatkan skor 403. Hasil tersebut menunjukkan bahwa siswa Indonesia masih kesulitan membuat hubungan antara konsep sains dan fenomena dalam kehidupan sehari-hari yang membutuhkan pemikiran tingkat tinggi (OECD,2019).

Survei awal terhadap 50 siswa sekolah menengah di Kabupaten Kuantan Singingi menunjukkan hanya $54 \%$ siswa yang memiliki pengetahuan tentang masalah PETI. $70 \%$ responden berikutnya menjawab bahwa guru belum pernah memberikan informasi tentang masalah PETI dalam pembelajaran (Astrid Riauda Putriana et al. 2020). Survei yang dilakukan di 3 SMP Kabupaten Siak terhadap siswa kelas VIII menunjukkan bahwa pengetahuan siswa masih sangat kurang tentang kebakaran lahan dan hutan. Analisis literasi lingkungan yang dilakukan oleh Wulan Indri Safitri et al. (2020) menunjukkan bahwa literasi lingkungan siswa pekanbaru berada pada kategori medium. Ini menunjukkan bahwa sebagian besar siswa sekolah menengah pertama belum mampu mengidentifikasi, menganalisis masalah lingkungan setempat, dan merencanakan tindakan untuk menyelesaikan masalah PETI, KARHUTLA, dan limbah domestik. Untuk menunjang kemampuan siswa tersebut diperlukan sumber belajar yang memadai dan strategi yang tepat.

Hasil observasi RPP di beberapa sekolah di Pekanbaru menunjukkan bahwa sumber belajar yang digunakan dalam pembelajaran terbatas pada buku dan media interaktif. Menurut Annisa Pusvita Sari, (2019) proses pembelajaran yang digunakan guru lebih sering menggunakan media objek langsung $(22,3 \%)$, gambar $(20,6 \%)$, power point $(18,3 \%)$, video $(16,9 \%)$, torso $(13,2 \%)$ dan komik $(8,7 \%)$. Dapat dikatakan bahwa proses pembelajaran yang dilaksanakan guru di sekolah masih sering menggunakan metode ceramah, serta media yang digunakan oleh guru masih belum bervariasi dan belum semuanya mengintegrasikan kondisi lingkungan yang relevan. Padahal menurut Nizwardi Jalinus dan Ambiyar, (2016) penggunaan sumber belajar yang tepat dapat menghasilkan pembelajaran yang berkualitas, menarik dan menyenangkan bagi siswa. Maka dari itu penulis berupaya untuk merancang media yang berkesan, ekonomis, menarik, dan 
kontekstual dengan kondisi lingkungan Riau dan dapat memunculkan respon dari peserta didik.

Salah satu media pembelajaran sederhana yang menarik dan masih jarang digunakan oleh guru adalah Flip chart. Flip Chart adalah suatu deret visual yang disusun atau digambar pada lembaran-lembaran kertas yang besar atau kertas koran yang dipasang bersama-sama pada bagian atasnya (puncaknya) (Nizwardi Jalinus dan Ambiyar, 2016). Flip chart ini adalah satu media yang mampu menggambarkan pertumbuhan atau perkembangan suatu peristiwa atau objek dengan jelas sehingga siswa bisa lebih sistematis dalam mempelajari suatu peristiwa atau ilmu.

Gambar dan simbol yang ada di dalam Flip chart dapat meningkatkan motivasi siswa untuk belajar (Nizwardi Jalinus dan Ambiyar, 2016). Menurut penelitian yang telah dilakukan oleh Desti Ratna Sari, (2018), isi Flip chart dapat meningkatkan pengetahuan siswa. Penelitian yang dilakukan oleh Hardianti M. et al. (2019) menunjukkan bahwa skor hasil belajar siswa diajarkan dengan menggunakan Flip chart adalah Tinggi dengan rata-rata nilai psotest 81.19 Sementara skor hasil belajar siswa yang diajarkan tanpa menggunakan media Flip chart learning adalah cukup dengan rata-rata 68.57. Namun saat ini Flip chart yang dikembangkan dalam pembelajaran IPA belum mengintegrasikan kondisi lingkungan yang relevan. Padahal integrasi gambar dan isu permasalahan lingkungan dalam Flip chart akan membuat siswa mencoba memecahakan permasalahan lingkungan dan mendapatkan pesan moral karena gambar yang ditampilkan lebih relevan dan sesuai dengan keadaan nyata. Kemampuan pemecahan masalah oleh siswa akan meningkatkan literasi sains siswa. Berdasarkan latar belakang tersebut penulis telah melakukan penelitian yaitu pengembangan media Flip chart berbasis Socio-Scientific Issue (SSI) pencemaran lingkungan untuk penguatan literasi sains siswa SMP.

\section{METODE PENELITIAN}

Jenis penelitian yang digunakan pada penelitian ini adalah penelitian Reseach and Development $(R \& D)$ dengan menggunakan model ADDIE yang dikembangkan oleh Robert Maribe Branch. Menurut Sugiyono (2019) model ADDIE terdiri dari lima tahapan yaitu analyze, design, development, implement dan evaluate. Namun pada penelitian ini, peneliti hanya melakukan sampai pada tahap development (pengembangan). Pada tahap analyze dilakukan analisis terhadap siswa, kurikulum, materi pembelajaran, dan indikator SSI dan literasi sains. Kemudian pada tahap design dirancang perangkat pembelajaran dan kerangka awal Flip chart. Pada tahap development di buat media Flip chart yang kemudian di validasi dan diujicoba untuk melihat kelayakannya sebagai sumber belajar berbasis SSI. Penilaian uji coba terbatas dilakukan menggunakan angket dengan skala Guttman. Data hasil pre-test dan post-tes akan dianalisis menggunakan rumus :

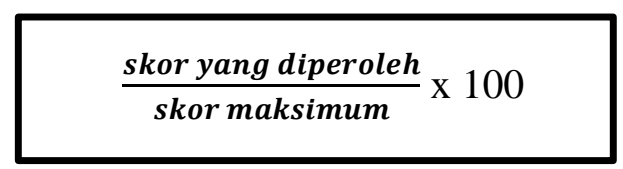

Gambar 1. Rumus Menghitung Nilai Pre-test dan Post-test

\section{HASIL DAN PEMBAHASAN}

Pengembangan media Flip chart yang dilakukan mendapatkan hasil validasi materi dan media dengan persentase $88,3 \%$ dan $87.5 \%$ dengan kategori sangat valid. Hasil Validasi materi dapat dilihat pada Tabel 1. 
Tabel 1. Rekapitulasi Hasil Validasi Materi Keseluruhan Indikator Flip Chart

\begin{tabular}{clcl}
\hline No & \multicolumn{1}{c}{ Indikator } & Persentase $(\boldsymbol{\%})$ & \multicolumn{1}{c}{ Kategori } \\
\hline $\mathbf{1}$ & Kurikukum & 88,9 & Sangat valid \\
\hline $\mathbf{2}$ & Isi & 86,5 & Sangat valid \\
\hline $\mathbf{3}$ & Socio-Scientific Issue & 89,3 & Sangat valid \\
\hline $\mathbf{4}$ & Literasi Sains & 89,3 & Sangat valid \\
\hline Rerata $:$ & 88,3 & Sangat valid \\
\hline
\end{tabular}

Berdasarkan Tabel 1 indikator yang mendapatkan skor dengan persentase tertinggi $(89,3 \%)$ adalah pada literasi sains dan SSI, indikator ini mendapatkan nilai tertinggi karena materi yang disajikan kaya akan indikator SSI dan literasi sains yang merupakan karakteristik dari pengembangan Flip chart yang dilakukan. Indikator kurikulum $(88,9 \%)$ dan isi $(86,5 \%)$ mendapatkan skor lebih rendah karena Flip chart masih memuat materi yang kurang sesuai dengan usia siswa dan bahasa yang masih terlalu tinggi untuk dipahami siswa. Tindak lanjut yang dilakukan peneliti adalah merevisi konten materi agar sesuai dengan usia siswa dan merevisi bahasa yang digunakan dalam Flip chart agar mudah dipahami siswa. Hasil validasi media dapat dilihat pada Tabel 2.

Tabel 2. Rekapitulasi Hasil Validasi Media Flip Chart.

\begin{tabular}{clcl}
\hline No & \multicolumn{1}{c}{ Indikator } & Persentase $(\boldsymbol{\%})$ & Kategori \\
\hline $\mathbf{1}$ & Tampilan & 87,02 & Sangat Valid \\
\hline $\mathbf{2}$ & Keterbacaan & 84,29 & Sangat Valid \\
\hline $\mathbf{3}$ & Kemudahan Penggunaan & 85,57 & Sangat Valid \\
\hline Rerata : & 87,5 & Sangat Valid \\
\hline
\end{tabular}

Berdasarkan Tabel 2 diketahui bahwa persentase rata-rata keseluruhan hasil validasi media Flip chart adalah $87,5 \%$ dengan kategori sangat valid. Indikator yang mendapatkan skor dengan persentase tertinggi $(87,2 \%)$ adalah aspek tampilan, aspek ini mendapatkan nilai tertinggi karena Flip chart memuat banyak kolaborasi warna, integrasi gambar dan grafik serta tulisan yang menarik guna memotivasi siswa untuk membaca materi yang disajikan. Hal ini sesuai dengan yang dikatakan oleh Nizwardi jalinus et al. (2018) bahwa paduan gambar, tulisan dan warna yang proporsional dapat menarik minat siswa untuk belajar. Indikator keterbacaan $(84,29 \%)$ dan kemudahan penggunaan $(85,57 \%)$ mendapatkan skor lebih rendah karena masih ada penulisan dan pengetikan yang perlu diperbaiki agar maksud dan tujuan materi yang disampaikan dalam Flip chart jelas. Selain itu juga masih perlu penyampaian strategi penggunaan Flip chart kepada siswa sebelum pembelajaran berlangsung agar siswa tidak bingung dalam menggunakan media ketika proses pembelajaran.

Flip chart yang telah divalidasi kemudian diuji cobakan secara terbatas kepada siswa kelas VIII SMPN 4 Pekanbaru. Uji Coba bertujuan untuk mengetahui respon atau tanggapan siswa terhadap keterpakaian media pembelajaran yang dikembangkan. Pada saat pengambilan data angket respon siswa, setiap siswa mengisi angket yang terdiri dari 20 pernyataan. Pernyataanpernyataan pada angket ini dibuat untuk melihat apakah Flip chart yang dibuat benarbenar dapat digunakan oleh siswa. Siswa juga diminta untuk mengerjakan pre-test dan posttest untuk melihat penguatan literasi sains yang didapatkan setelah membaca Flip chart. Uji coba terbatas yang diberikan kepada 
siswa dilaksanakan secara online. Uji coba di lakukan online karena mengingat penyebaran virus korona yang mengharuskan semua instansi pendidikan melakukan pembelajaran daring agar terhindar dari bahaya yang ditimbulkan oleh virus ini. Berita yang diterbitkan oleh kompas.com (2020) memaparkan bahwa Menteri Pendidikan dan Kebudayaan (Mendikbud) Nadiem Makarim mengatakan, "pembelajaran di perguruan tinggi pada semua zona masih wajib dilaksanakan secara daring hingga ada kebijakan lebih lanjut".

Flip chart merupakan media yang dipersiapkan untuk digunakan dan diterapkan secara langsung oleh siswa. Namun supaya responden tetap bisa menilai bagaimana penggunaan Flip chart ini meskipun pada masa pandemi dengan sistem pembelajaran online, peneliti mengemas teknik penggunaan Flip chart dengan cara memvideokan bentuk asli penggunaan media ini dan mengirimkan file desain dalam bentuk format .pdf agar dapat dibaca oleh responden. Uji coba dengan siswa SMPN 4 Pekanbaru dilakukan dengan menggunakan platform Whatsapp karena sekolah tersebut menggunakan platform ini selama pembelajaran daring.

Angket responden dan soal pre-test dan post-test di buat menggunakan Google Form.
Untuk pre-test dan post-test dibatasi waktunya dengan sistem time limiter selama 20 menit agar hasil jawaban yang didapatkan sesuai dengan ketentuan waktu yang diinginkan. Uji coba terbatas berlangsung dalam 2 hari yaitu tanggal 26-27 Agustus 2020. Uji Coba ini dilakukan secara online dengan mengirimkan video penggunaan, pdf isi materi Flip chart, link pre-test, post-test, dan angket respon melalui platform whatssapp. Tahapan uji coba tahap II hari pertama dimulai dengan perkenalan dengan semua siswa kelas VIII.3, kemudian dilanjutkan dengan menjelaskan tentang media Flip chart. Setelah itu melalui whatsapp peneliti mengirimkan link absen pre-test, video penggunaan Flip chart sekaligus materi Flipchart pertemuan 1, dan soal post-test. Tahapan uji coba hari ke dua di mulai dengan mengirimkan video penggunaan sekaligus isi materi Flip chart dan didampingi oleh link angket respon siswa.

Berdasarkan hasil analisis data diperoleh respon uji coba oleh siswa SMPN 4 Pekanbaru terhadap Flip chart dengan kategori sangat baik yaitu mendapatkan skor 88,1 . Penjabaran hasil analisis respon siswa terhadap tiap aspek dapat dilihat pada Tabel 3.

Tabel 3. Hasil Angket Respon Siswa terhadap Flip Chart

\begin{tabular}{cccc}
\hline No & Indikator & Skor & Kategori \\
\hline $\mathbf{1}$ & Tampilan & 92 & SB \\
\hline $\mathbf{2}$ & Materi & 87 & SB \\
\hline $\mathbf{3}$ & Manfaat & 90 & SB \\
\hline $\mathbf{4}$ & Literasi Sains & 83,3 & SB \\
\hline Rerata : & & 88,75 & SB \\
\hline Ket $=$ SB : Sangat Baik & &
\end{tabular}

Berdasarkan Tabel 3 dapat dilihat bahwa media Flip chart yang telah dikembangkan sangat baik dengan skor ratarata 88,75. Hasil analisis respon dengan skor sangat baik tertinggi adalah tampilan yaitu 92 . Aspek tampilan Flip chart merupakan salah satu karakteristik yang membedakan dengan buku paket yang sering digunakan di sekolah. Flip chart di desain dengan tampilan kombinasi huruf, warna dan gambar relevan yang dapat mendukung penyampaian materi. menurut Riza Rosita, (2018) Flip Chart berperan dalam meningkatkan partisipasi belajar, karena sajian materi yang disampaikan lebih menarik jika dibandingkan belajar dengan hanya menggunakan buku paket. Aspek ini mendapatkan skor tertinggi karena kombinasi warna tulisan dan gambar yang proporsional membuat siswa tertarik untuk membaca materi pada Flip chart yang 
dikembangkan.

Aspek selanjutnya yang mendapatkan skor tertinggi ke dua adalah pada aspek manfaat yaitu dengan skor 90. Paduan isu lingkungan sekitar yang relevan dengan desain tampilan yang proporsional dapat membuat pembelajaran menjadi menarik dan menyenangkan sehingga meningkatkan keinginan siswa untuk mengetahui lebih dalam mengenai materi pembelajaran. Flip chart memuat banyak warna dan gambar yang dapat membuat pembelajaran menjadi terfokus dan menarik serta menyenangkan sehingga memotivasi siswa untuk belajar. Hal ini sesuai dengan pendapat dari Hardianty et al. (2018) Flip Chart media yang digunakan sangat baik dalam memfokuskan siswa terhadap materi yang diajarkan karena materi presentasi didukung dengan gambar relevan yang mendukung teori pembelajaran. Gambar yang memuat tentang isu lingkungan juga membuat siswa untuk tertarik mempelajari lingkungan dan mulai sadar akan pentingnya mencintai alam. Hal ini sesuai dengan Evi Suryawati et al. (2020) bahwa adanya korelasi antara peningkatan pengetahuan siswa dengan sikap siswa terhadap lingkungan dimana sikap siswa ini akan berpengahruh terhadap kepribadian dan tanggung jawab terhadap lingkungan.

Skor dengan kriteria sangat baik selanjutnya yang didapatkan dari hasil analisis yaitu aspek materi yaitu 87. Aspek materi ini meliputi bahasa yang digunakan, sistematika materi, isu terkini, dan gambar pendukung materi. Bahasa yang digunakan Flip chart adalah bahasa Indonesia. Untuk bahasa ilmiah dan bahasa inggris diberikan penjelasan agar mudah dimengerti oleh siswa. Materi Flip chart dijabarkan sesuai dengan tujuan pembelajaran agar siswa mudah memahami pembelajaran karena beberapa pokok materi baru bisa dicapai jika point tujuan pembelajaran sebelumnya telah dikuasai. Isuisu yang diterapkan dalam Flip chart merupakan isu terkini yang berkaitan dengan lingkungan. Gambar pendukung pada Flip chart juga disajikan dengan jelas supaya gambar tersebut bermakna dan dapat memperkuat penyampaian materi yang diberikan oleh siswa. hal ini sesuai dengan pendapat Riza Rozita, (2018) jika materi yang disajikan sesuai dengan tujuan pembelajaran dan penyajian materi menggunakan bahasa yang sederhana maka akan mudah dimengerti dan dipahami oleh siswa.

Aspek literasi sains mendapatkan skor dengan kategori baik yaitu 83,3 . Aspek ini mendapatkan skor dengan kategori baik karena materi pada Flip hart yang berupa pengetahuan konten, prosedural dan epistemic yang berbasis isu lingkungan yang relevan dengan kondisi saat ini membantu siswa untuk paham kaitan antar konsep sains, dapat mengembangkan kompetensi penyelidikan ilmiah dan dapat mengaitkan materi dengan permasalahan sederhana di kehidupan nyata. Hal ini sesuai dengan yang dikatakan oleh Zeidler et al. (2019) Integrasi sosiokultural baik secara implisit maupun eksplisit pada pendidikan sains akan meningkatkan literasi sains.

Penguatan literasi sains siswa ditunjukkan oleh hasil peningkatan nilai pretes, post-test. Soal pre-test dan post-test di rancang untuk mengetahui pengetahuan literasi sains siswa. Hasil perhitungan nilai pre-test dan post-test di dapatkan bahwa adanya peningkatan dari rata-rata 61 dengan kategori kurang menjadi 81 dengan kategori baik. Dari hasil tersebut dapat dikatakan bahwa adanya penguatan literasi sains sebelum dan sesudah menggunakan media Flip chart pertemuan 1. Jabaran penguatan literasi sains siswa pada aspek kompetensi sains dapat dilihat pada Gambar 2. 


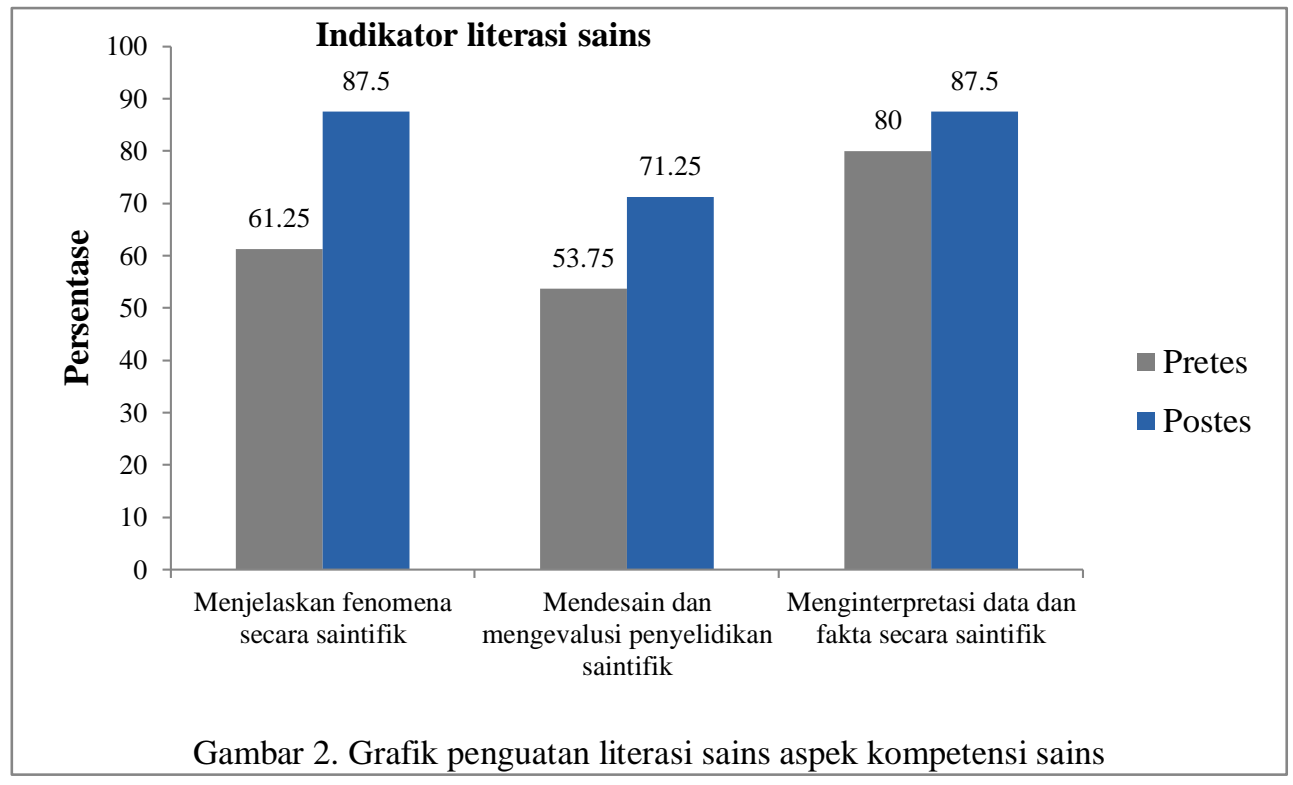

Gambar 2 menunjukkan bahwa sebelum diterapkannya perangkat pembelajaran Flip chart persentase skor masing-masing indikator berkisar 53,73 sampai 80 dan setelah diterapkannya perangkat Flip chart dalam pembelajaran persentase skor masingmasing indikator mencapai 71,25 sampai 87,5. Berdasarkan hasil tersebut, dapat dikatakan bahwa adanya penguatan literasi sains siswa setelah menggunakan Flip chart.

Dari grafik tersebut juga dapat dilihat bahwa kompetensi menjelaskan fenomena secara saintifik dan menginterpretasikan data dan fakta secara saintifik mendapatkan persentase penguatan tertinggi yaitu sangat baik. Kompetensi menjelaskan fenomena secara ilmiah adalah kemampuan memberikan penjelasan ilmiah dengan menggunakan teoriteori eksplanatoris, informasi, dan fakta serta pemahaman tentang kaitan antara konsep materi. Penguatan yang tinggi pada aspek kompetensi ini disebabkan pengetahuan konten, prosedural dan epistemik berbasis SSI yang dimuat pada Flip chart merupakan indikator-indikator yang bertujuan untuk mengembangkan kompetensi menjelaskan fenomena secara saintifik.

Orientasi isu lingkungan yang disajikan dalam Flip chart merupakan isu-isu yang ada di sekitar siswa dan sangat berkaitan dengan kehidupan nyata sehingga memotivasi siswa untuk memaknai materi pelajaran yang sedang dipelajarinya. Implikasi dari kemauan siswa untuk memaknai materi pembelajaran adalah: 1) siswa mampu mengingat dan menerapkan pengetahuan ilmiah, 2) mampu mengidentifikasi, menggunakan serta memberikan penjelasan umum yang representatif mengenai isu yang terkait dengan materi, 3) mampu memberikan prediksi, 4) dapat mengaitkan hubungan antara permasalahan sosial yang terkait dengan sains. 4 kemampuan tersebut menggambarkan kompetensi menjelaskan fenomena secara saintifik. Hal ini sesuai dengan Ely Rohmawati et al. (2018) yang menyatakan bahwa pembelajaran berkonteks isu lngkungan dapat meningkatkan literasi sains dan dapat membantu siswa menjadi warga negara yang bertanggung jawab, karena pembelajaran tersebut mempersiapkan siswa untuk mengkaji dan meneliti masalah sosial yang berhubungan dengan materi sains.

Kompetensi menginterpretasikan data dan fakta secara saintifik juga mendapatkan penguatan tertinggi karena Flip chart memaparkan gambar, grafik dan tabel yang dapat mengembangkan kemampuan siswa dalam menerjemahkan data. Kemampuan siswa dalam menerjemahkan data dari satu representasi ke bentuk lainnya, misalnya menerjemahkan makna dari grafik dan 
kemudian dikaitkan dengan materi merupakan salah satu ciri bahwa adanya pengembangan kompetensi siswa dalam menginterpretasikan data dan fakta secara ilmiah (OECD, 2017).

Kompetensi ini mendapatkan nilai yang tinggi karena pembahasan soal hanya menguji kemampuan dasar siswa pada aspek kompetensi interpretasi data dan fakta secara saintifik. Soal yang disajikan menguji kemampuan siswa menerjemahkan data dan kemampuan menafsirkan data. Sedangkan untuk kemampuan untuk mengevaluasi argumen ilmiah belum dapat dieksplore dari kemampuan siswa pada materi awal ini. Menurut Yunus Abidin et al. (2018) kompetensi menginterpretasikan data dan fakta secara saintifik merupakan kemampuan membuat dan membaca data untuk membuktikan bahwa hasil penelitian yang dipaparkan atau yang sedang dilakukan sahih dan dapat diandalkan. Kemampuan tersebut akan dapat dikuasai pada saat materi pertengahan. Materi pembelajaran yang disajikan semakin lama akan semakin dalam sehingga semakin lama kompetensi sains akan dipahami lebih dalam.

Kompetensi mendesain dan mengevaluasi penyelidikan saintifik mendapatkan skor 71,25 dengan kategori cukup baik. Menurut Yunus abidin et al. (2018) kompetensi mendesain dan mengevaluasi penyelidikan saintifik merupakan kemampuan untuk berkolaborasi, berkomunikasi, berpikir kritis, dan mengevaluasi dalam memahami tujuan penyelidikan ilmiah untuk menghasilkan pengetahuan yang andal tentang alam semesta. Flip chart menyajikan

\section{KESIMPULAN}

Flip chart yang dikembangkan mendapatkan hasil sangat valid dengan skor $88,3 \%$ untuk materi dan $87,5 \%$ untuk validasi media. Terdapat penguatan literasi sains siswa setelah menggunakan media Flip chart. Penguatan tersebut terlihat dari peningkatan nilai pre-test dan post-test yaitu dari 62 menjadi 81. Peningkatan pre-test dan post-test menggambarkan adanya penguatan literasi pengembangan isu dalam bentuk jurnal dan bagan yang mempu menggali kemampuan siswa dalam mengembangkan kemampuan pemecahan masalah melalui penyelidikan sains baik berupa studi jurnal maupun penelitian secara langsung. Sesuai dengan hasil validasi, kompetensi ini mendapatkan skor terendah karena Flip chart hanya mampu menampilkan gambar, bagan serta penjelasan singkat yang mengembangkan kemampuan dasar dari kompetensi mendesain dan mengevaluasi penyelidikan saintifik (mengeksplorasi topik baru).

Kesan umum yang dapat digambarkan dari angket respon, perbedaan nilai pre-test dan post-test hasil uji coba adalah bahwa Flip chart dapat membuat siswa tertarik dan fokus dengan materi pembelajaran karena desain yang menarik dan materi yang disampaikan singkat, padat dan jelas. Flip chart yang menampilkan pengetahuan konten, prosedural dan epistemic yang dikemas dengan strategi orientasi isu, pengembangan dan sintesis terkait lingkungan sehingga memberikan penguatan terhadap kemampuan siswa dalam menjelaskan fenomena secara saintifik, mendesain dan mengevaluasi penyelidikan saintifik dan menginterpretasi data dan fakta secara saintifik. Penguatan tersebut tergambar dari perbedaan antara nili pre-test dan posttest yang disajikan. Berdasarkan analisis terhadap data hasil validasi dan uji coba terbatas dapat diketahui bahwa media Flip chart yang telah dikembangkan dapat digunakan dalam pembelajaran dan berpotensi untuk penguatan literasi sains siswa SMP.

sains pada kompetensi menjelaskan fenomena secara ilmiah dari $61,25 \%$ (rendah) menjadi $87,5 \%$ (sangat baik), kompetensi merancang dan mengevaluasi inkuiri ilmiah dari 53,75\% (rendah) menjadi 71,25\% (cukup), dan kompetensi menginterpretasikan data dan bukti secara ilmiah dari $80 \%$ (baik) menjadi $87,5 \%$ (sangat baik). Penguatan tersebut didukung dengan angket siswa saat 
menggunakan Flip chart yaitu 88,75\%. Flip chart tentang pencemaran lingkungan yang dikembangkan dalam kategori sangat baik dapat digunakan sebagai sumber belajar SMP. Berdasarkan penelitian yang telah dilakukan direkomendasikan untuk mengembangkan

\section{DAFTAR PUSTAKA}

Amining R., Herwati S. dan Hadi Suwono. 2018. Pengaruh Pembelajaran Diskusi Kelas Menggunakan Isu Sosiosains terhadap Literasi Sains Mahasiswa Baru pada Kemampuan Akademik Berbeda. Jurnal Pendidikan. 3 (8) : 980-989.

Annisa P.S. 2019. Pengembangan Buku Komik sebagai Media Pembelajaran IPA pada Materi Pemanasan Global Kelas VII SMP. Skripsi. Fakultas Keguruan dan Ilmu Pendidikan Universitas Riau. Riau

Astrid R. P., Evi S., Fitra S., Zulfarina. 2020. Pengembangan LKPD berbasis Socio Scientific Issue (SSI) pada Pembelajaran IPA SMP Kelas VII. Jurnal PAJAR (Pendidikan dan Pengajaran). 4 (1) : 8089

Ayunda Pininta. 2020. Mendikbud : Perguruan Tinggi di Semua Zona Dilarang Tatap Muka. Kompass.com . 16 Juni 2020.

BMKG. 2019. Asap Pekanbaru Menyentuh Ambang Batas. Tribunnews.com. 14 September 2019.

Desti R.. 2018. Pengembangan Media Pembelajaran Flip Chart untuk Meningkatkan Pengetahuan Bencana Gempa Bumi Pada Siswa di SMPN 1 Cawas. Skripsi. Fakultas Keguruan dan Ilmu Pendidikan Universitas Muhammadiyah Surakarta. Surakarta.

Depdiknas. 2008. Panduan Penulisan Butir Soal. Jakarta : Direktorat Pembinaan SMA Ditjen Pendidikan Dasar dan Menengah.

Ely Rohmawati, Wahono Widodo dan media Flip chart dengan materi yang berbeda atau melanjutkan ke-tahap selanjutnya dari penelitian pengembangan yaitu implementation dan evaluation agar dapat diketahui tingkat keterpakaian media Flip chart ini.

Rudiana Agustin. 2018. Membangun Kemampuan Literasi Sains melalui pembelajaran berkonteks Socio-Scientific Issue berbantuan Media WEBLOG. Jurnal Penelitian Pendidikan IPA. 3 (1): 8-14

Evi Suryawati, F.Suzanti, Zulfarina, A.R Putriana, L. Febrianti. 2020. The implementation Of Local Environmental Problembased Learning Student Worksheets To Strengthen Environmental Literacy. Jurnal Pendidikan IPA Indonesia. 9 (2) : 169178

Hardianti M, Nurhayati B, dan Muhammad Junda. 2019. The Effect of Using Flip Chart Learning Media Toward Student Biology Learning Outcomes. International Jurnal of Advances in Science Engineering And Technology. 6 (2) $: 5-10$

Ika B.Y, Sri R., Fauziatul F. 2016. POGIL Berkonteks Socio-Scientific Issues (SSI) dan Literasi Sains Siswa SMK. Pros.Semnas pend IPA Pascasarjana UM vol 1: 601-614

Kaidir, B. I, Sujianto, Rifardi. 2019. Waste Management in Pekanbaru City, Riau Province, Indonesia Using Normative System Modeling. Social Science. 8 (1) : 6-11

Nizwardi J. dan Ambiyar. 2016. Media dan Sumber Pembelajaran. KENCANA : Jakarta

Pazli. 2020. Unlicensed Gold Mining and Agricultural Land in Kuantan Singingi District Province of Riau, Indonesia. 
Research Journal of Agriculture and Forestry Sciences. 8(1) : 65-71

Riza Rosita. 2017. Pengembangan Media Pembelajaran Biologi berbentuk Flip Chart pada Materi Jamur untuk Siswa Kelas X. Skripsi. Fakultas Keguruan dan Ilmu Pendidikan Universitas Jambi.

Sugiyono. 2019. Metode Penelitian \& Pengembangan (Research and depelopment). Bandung: Alfabeta

OECD. 2019. PISA 2018 : Insigths and interpetations : OECD Publishing

Wulan I.S., Evi S., Yustina. 2020. Enviromental Literacy Analysis of Junior High School Students in Pekanbaru.
Journal of Education Science 4 (1) : 116123

OECD. 2017. Asessment and Analitycal Framework Mathematics, Reading, Science, Problem Solving, and Financial Literacy S.I : OECD Publishing.

Yunus Abidin, Tita Mulyanti, Hana Yunansah. 2018. Pembelajaran Literasi : Strategi Meningkatkan Kemampuan Literasi Matematika, Sains, Membaca, dan Menulis. Bumi Aksara : Jakarta

Zeidler L. Dana, Benjamin C.Herman, Troy D. Sadler. 2019. New Direction in Socioscientific Isuues Research. Diciplinary and Interdisciplinary Science education Research. 1(11) : 1-9 